J. Appl. Glycosci., 53, 249-254 (2006)

(C) 2006 The Japanese Society of Applied Glycoscience

Regular Paper

\title{
Effects of Feeding Sialyllactose and Galactosylated $N$-Acetylneuraminic Acid on Swimming Learning Ability and Brain Lipid Composition in Adult Rats
}

\author{
(Received March 6, 2006; Accepted June 21, 2006) \\ Fumihiko Sakai, ${ }^{1}$ Yoshihiro Ikeuchi, ${ }^{1}$ Tadasu Urashima, ${ }^{2}$ Michio Fujihara, ${ }^{3}$ \\ Kenzo Ohtsuki ${ }^{3}$ and Shuichi Yanahira ${ }^{1, *}$ \\ ${ }^{1}$ Institute of Food Hygiene, Snow Brand Milk Products Co., Ltd. (1-1-2, Minamidai, Kawagoe 350-1165, Japan) \\ ${ }^{2}$ Graduate School of Food Hygiene, Obihiro University of Agriculture and Veterinary Medicine \\ (Nishi 2sen 11banchi, Obihiro 080-8555, Japan) \\ ${ }^{3}$ Laboratory of Genetical Biochemistry and Signal Biology, Graduate School of Medical Sciences, Kitasato University \\ (1-15-1, Kitasato, Sagamihara 228-8555, Japan)
}

\begin{abstract}
The learning behavior of adult rats was studied using a water-filled multiple T-maze apparatus and a Morris swimming-maze after feeding lactose, galactosyllactose (GL), $N$-acetylneuraminic acid (Neu5Ac), sialyllactose (SL) or galactosylated $N$-acetylneuraminic acid (GN) and a control diet. The learning behavior tended to improve in the groups fed SL or GN when compared with the other groups. The concentrations of gangliosides and GM3 in brain were significantly higher in the groups fed SL or GN. The data show that the feeding of SL or GN to adult rats raised the brain ganglioside and GM3 contents, which may be related to improvement in the swimming learning behavior.
\end{abstract}

Key words: sialyllactose, galactosylated $N$-acetylneuraminic acid, swimming learning behavior, brain ganglioside

Sialic acid, which occurs at the non-reducing ends of carbohydrate moieties of animal glycoproteins and gangliosides, and of free oligosaccharides in milk/colostrum, ${ }^{1-3)}$ has many biological functions. ${ }^{4)}$ It is generally considered that sialic acid inhibits the attachment of pathogenic viruses, bacteria and bacterial toxins to the epithelial cells in the colon, bronchus and lung, etc. ${ }^{5,6)}$ and that sialic acid in brain gangliosides participates in synaptogenesis and neural transmission. ${ }^{3,7)}$ As sialic acid is also contained in carbohydrate moieties of the glycoconjugates in foods, including milk or colostrums, ${ }^{8-11)}$ both infants and adults consume sialic acid in their diets. Wang and Brand-Miller have suggested that sialic acid from glycoconjugates of milk may be absorbed in the infant small intestine and be used for brain ganglioside formation., ${ }^{3,7}$ The absorption of sialic acid in the small intestine has not, however, been fully established to date.

In this study, we fed sialyllactose, which has been found in bovine colostrum and cheese whey, or galactosylated $\mathrm{N}$-acetylneuraminic acid, which had been synthesized as described in our previous study, ${ }^{12}$ to adult rats, and studied their swimming learning behavior and brain lipid composition.

\section{MATERIAL AND METHODS}

Materials. Free $\mathrm{N}$-acetylneuraminic acid (Neu5Ac) was commercially obtained from Snow Brand Milk Products Co., Ltd. Galactosylated $N$-acetylneuraminic acid (GN) was synthesized from Neu5Ac and lactose with $\mathrm{Ba}$ -

* Corresponding author (Tel. +81-49-242-8166, Fax. +81-49-2428504, E-mail: s-yanahira@ snowbrand.co.jp). cillus circulans $\beta$-galactosidase as described in our previous paper. $^{12)}$ GN was a mixture of $\mathrm{Gal}(\beta 1-8) \mathrm{Neu} 5 \mathrm{Ac}$ (45\%), Gal( $\beta 1-9) N e u 5 A c(45 \%)$ and $\operatorname{Gal}(\beta 1-3) \mathrm{Gal}(\beta 1-8)$ Neu5Ac (10\%). Sialyllactose (SL) was separated from cheese whey as follows. ${ }^{13,14)}$ Cheese whey $(1500 \mathrm{~kg})$ was concentrated by evaporation and the lactose partially removed by crystallization. The supernatant was passed through an anion exchange resin (Dowex $1 \times 4$ ), which was then eluted with a large volume of water to wash out non-acidic solutes. The SL, which had been adsorbed by the resin, was eluted using a linear gradient of $0-0.06 \mathrm{M}$ sodium acetate. The eluate was deionized using electron dialysis and lyophilized to obtain $96 \%$ pure SL of which $87 \%$ was Neu5Ac( $\alpha 2-3) \mathrm{Gal}(\beta 1-4) \mathrm{Glc}$ and $13 \%$ was Neu5 $\operatorname{Ac}(\alpha 2-6) \mathrm{Gal}(\beta 1-4) \mathrm{Glc}$, as determined by high-performance liquid chromatography. Galactooligosaccharide (GL) was prepared by a transglycosylation reaction catalyzed by Aspergillus oryzae $\beta$-galactosidase according to the method of Deya et al ${ }^{15)}$ The GL was purified by charcoal column chromatography. The composition of GL was $75 \%$ trisaccharide, $20 \%$ tetrasaccharide and $5 \%$ pentasaccharide. The main structure was $\operatorname{Gal}(\beta 1-6) \mathrm{Gal}(\beta 1-4) \mathrm{Glc}$.

Animals and Diets. Thirty-six male Sprague Dawley (SD) rats (8 weeks: Charles River Inc.), with an initial mean weight of $300 \mathrm{~g}$, were housed under controlled ambient temperature $\left(22 \pm 2^{\circ} \mathrm{C}\right)$ conditions with $55 \pm 5 \%$ humidity and lighting (light cycle from to $12 \mathrm{~h}$ ) with free access to food and water. The control group $(n=6)$ was fed the AIN-96G (Oriental Yeast Co., Ltd.) diet while the treated groups $(n=6)$ were fed the diets containing $1 \%$ lactose, $1 \% \mathrm{GL}, 1 \% \mathrm{Neu} 5 \mathrm{Ac}, 1 \% \mathrm{SL}$ or $1 \% \mathrm{GN}$, replacing sucrose in the control diet (Table 1). After a one-week period of adaptation to the control diet, the rats were ran- 




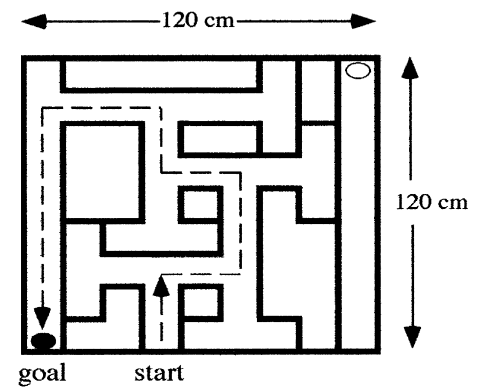

Water-filled multiple T-maze apparatus.

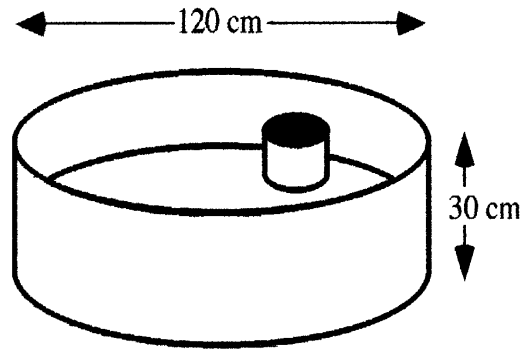

Morris swimming-maze apparatus.

Fig. 1. Experimental design and apparatus of swimming behavior.

Table 1. Composition of experimental diets (\%).

\begin{tabular}{lrrrrrr}
\hline Components & Cont & Lac & GL & Neu5Ac & SL & GN \\
\hline$\alpha$-Corn starch & 13.2 & 13.2 & 13.2 & 13.2 & 13.2 & 13.2 \\
Corn starch & 39.7 & 39.7 & 39.7 & 39.7 & 39.7 & 39.7 \\
Casein & 20.0 & 20.0 & 20.0 & 20.0 & 20.0 & 20.0 \\
Sucrose & 12.0 & 11.0 & 11.0 & 11.0 & 11.0 & 11.0 \\
Soybean oil & 7.0 & 7.0 & 7.0 & 7.0 & 7.0 & 7.0 \\
Cellurose & 5.0 & 5.0 & 5.0 & 5.0 & 5.0 & 5.0 \\
$\quad \begin{array}{l}\text { Mineral mixture (AIN- } \\
\quad 33 G)\end{array}$ & 3.5 & 3.5 & 3.5 & 3.5 & 3.5 & 3.5 \\
Vitamin mixture (AIN- & 1.0 & 1.0 & 1.0 & 1.0 & 1.0 & 1.0 \\
$\quad$ 93G) & 0.3 & 0.3 & 0.3 & 0.3 & 0.3 & 0.3 \\
L-Cystine & 0.25 & 0.25 & 0.25 & 0.25 & 0.25 & 0.25 \\
Choline bitartrate & - & 1.0 & - & - & - & - \\
Lactose & - & - & 1.0 & - & - & - \\
Galactooligosaccharide & - & - & - & 1.0 & - & - \\
$\quad N$-acetylneuraminic acid & - & - & - & - & 1.0 & - \\
Sialyllactose & - & - & - & & - & 1.0 \\
Galactosylated & - & - & - & - & - & \\
$\quad \quad N$-acetylneuraminic acid & & & & & & \\
\hline
\end{tabular}

Cont, control; Lac, lactose; GL, galactooligosaccharide; Neu5Ac, $\mathrm{N}$-acetylneuraminic acid, SL, sialyllactose; GN, galactosylated $\mathrm{N}$ acetylneuraminic acid.

domly assigned to five diet groups with six rats in each group. They were fed the experimental diets (Table 1) for two weeks; the diets and demineralized water were provided ad libitum. Body weight and food intake were recorded daily. The maze learning test was conducted using a multiple T-maze apparatus filled with water after feeding of the experimental diets for 7-10 days, and then a Morris swimming-maze was performed after that for 1114 days (Fig. 1). After a 2-week feeding period, the rats were fasted for $17 \mathrm{~h}$, anesthetized with diethyl ether, and plasma samples and brain were collected. They were stored at $-44^{\circ} \mathrm{C}$ immediately after collection.

Swimming learning test. The T-maze learning test was conducted by the method of using a water-filled multiple T-maze apparatus as shown in Fig. $1 .{ }^{16)} \mathrm{T}$-mazes and linear waterways $(30 \mathrm{~cm}$ height $\times 12.5 \mathrm{~cm}$ width) were arranged in a water tank $(120 \times 120 \times 40 \mathrm{~cm})$ and a stand (21.5 cm height) was placed in the goal. The tank was filled with water at $23 \pm 1{ }^{\circ} \mathrm{C}$ up to a height of $18 \mathrm{~cm}$ and skim milk was added to produce a white coloration. Rats were trained to swim to the goal a day before the test. Rats were preliminarily led to the goal by hand at the beginning of the test. The final examinations were performed twice daily and continued for four days (after 710 days feeding experimental diets). The length of time (seconds) taken for each rat to swim from start to goal was determined and average values were calculated for the tests performed twice in a day.

Another maze learning study was performed using the Morris-swimming maze apparatus shown in Fig. $1 .^{17)}$ For this test, a round tank was filled with water at $23 \pm 1^{\circ} \mathrm{C}$ to a height of $18 \mathrm{~cm}$ and skim milk was added as above. A stand $(16.0 \mathrm{~cm}$ height $)$ was arranged in the optimal position as the goal in the water tank. In this experiment, each rat was placed on the water in a position that was opposite the goal. The examinations were performed twice daily and continued for four days (after 11-14 days feeding experimental diets). The length of time (seconds) taken for each rat to swim from start to goal was determined and average values were calculated for the tests performed twice in a day.

Determination of the sialic acid content in rat serum. The sialic acid content of the rat serum was assayed using a specific kit (Kyokuto Seiyaku Co., Ltd., Tokyo, Japan).

Extraction of whole lipids from rat brain. The total lipids were extracted from the rat brain using chloroform/ methanol/water (4:8:3, v/v/v) ${ }^{18)}$ Each brain was homogenized with $8 \mathrm{~mL}$ of water, after which methanol $(20 \mathrm{~mL})$ and chloroform $(10 \mathrm{~mL})$ were added with stirring. The stirring was continued for $30 \mathrm{~min}$ and the resulting emulsion was centrifuged at $3,000 \mathrm{rpm}$ for $15 \mathrm{~min}$. The upper layer was transferred into a $100 \mathrm{~mL}$ measuring flask. Chloroform/methanol $(2: 1, \mathrm{v} / \mathrm{v}), 20 \mathrm{~mL}$, was added to the residue to re-extract the lipids, and the extract was transferred into the measuring flask. The solution in the flask, after adjusting to $100 \mathrm{~mL}$ with chloroform/methanol $(1: 1, \mathrm{v} / \mathrm{v})$ was used for the determination of triacylglycerol, cholesterol, phospholipid and gangliosides.

Determination of lipids. The triacylglycerol, cholesterol and phospholipid contents were determined using the 
acetylacetone method (Triglyceride test Wako, Wako Pure Chemical Co., Ltd., Tokyo, Japan), an enzymatic method (Determina, TC555, Kyowa Medics, Ltd., Tokyo, Japan) and the permanganate-incineration method (Phospholipid test Wako, Wako Pure Chemical Co., Ltd., Tokyo, Japan), respectively.

Determination of gangliosides. The purification of gangliosides from a part of the lipid extracts was performed by the method of Ren et al . using chromatography on DEAE-Sephadex and Iatrobead columns. ${ }^{19)}$ The sialic acid content of the gangliosides was determined by the resorcinol-HCl method. The content of each ganglioside (GM3, GM1, GD3, GD1a, GD2, GD1b, GT3 and GQ1b) was determined by high performance liquid chromatography (HPLC) using a Waters LC Module 1 with an Aquasil SS column $(6 \times 200$ mm, Senshu Kagaku, Tokyo, Japan), as described by Ando et al ${ }^{20)}$ The mobile phases were 10:68:22 (v/v/v) and 5:43:52 (v/v/v) acetonitrile/2propanol $/ 50 \mathrm{~mm}$ tetramethylammonium chloride. Elution was done using a linear gradient at $40^{\circ} \mathrm{C}$ at a flow rate of $1.3 \mathrm{~mL} / \mathrm{min}$. Eluted materials were detected by measuring the absorbance at $208 \mathrm{~nm}$.

Statistical analysis. Values are expressed as means \pm SD. The statistical significance of changes was assessed at the 5\% level using analysis of variance (ANOVA) followed by the Tukey multiple comparisons.

\section{RESULTS AND DISCUSSION}

\section{T-maze learning test.}

The data for the length of time taken to swim from start to goal using a multiple T-maze apparatus are shown in Table 2 for each group of rats. The groups were those that had been fed the control diet, lactose, GL, Neu5Ac, SL or GN. This length of time was shorter in the groups that had been fed GN or SL than in the other groups during one day of the trial, but the differences were not statistically significant.

\section{Morris-swimming maze test.}

The data for the length of time taken to swim from start to goal with the Morris swimming-maze apparatus are shown in Table 3 for each group of rats. The time for this was shorter in the GN or SL groups than in the other groups during days one and two of the trial. This tendency was clearer in this test than in that with the multiple T-maze.

\section{Body weight and brain weight.}

Significant differences were not observed in body weight or food efficiency among the six groups during the feeding trials, and no changes in the brain weight were observed (Table 4).

Table 2. The effects of experimental diets on T-maze swimming-behavior in rats (twice/day).

\begin{tabular}{ccccccc}
\hline Trials (day) & Cont & Lac & GL & Neu5Ac & SL & GN \\
\hline 1.0 & $31.6 \pm 6.1$ & $35.6 \pm 6.5$ & $34.7 \pm 9.8$ & $27.5 \pm 5.7$ & $24.3 \pm 7.3$ & $24.6 \pm 2.0$ \\
2.0 & $21.1 \pm 4.2$ & $24.2 \pm 11.8$ & $20.0 \pm 5.0$ & $18.6 \pm 4.4$ & $16.1 \pm 4.8$ & $16.9 \pm 3.7$ \\
3.0 & $11.4 \pm 2.2$ & $12.9 \pm 1.1$ & $13.0 \pm 2.7$ & $11.1 \pm 2.9$ & $11.7 \pm 1.3$ & $11.4 \pm 2.6$ \\
4.0 & $9.3 \pm 3.2$ & $9.0 \pm 1.3$ & $10.1 \pm 2.7$ & $9.1 \pm 2.2$ & $11.0 \pm 3.3$ & $9.4 \pm 1.8$ \\
\hline
\end{tabular}

Values are means $\pm \mathrm{SD}$ \{second $(n=6)$ \}. Cont, control; Lac, lactose; GL, galactooligosaccharide; Neu5Ac, $N$-acetylneuraminic acid, SL, sialyllactose; GN, galactosylated $N$-acetylneuraminic acid.

Table 3. The effects of experimental diets on Morris-maze swimming-behavior in rats (twice/day).

\begin{tabular}{ccccccc}
\hline Trials (day) & Cont & Lac & GL & Neu5Ac & SL & GN \\
\hline 1.0 & $70.2 \pm 33.9$ & $64.8 \pm 30.2$ & $63.3 \pm 21.4$ & $63.5 \pm 23.7$ & $38.6 \pm 10.8$ & $41.8 \pm 13.4$ \\
2.0 & $31.7 \pm 11.2$ & $30.7 \pm 12.4$ & $28.0 \pm 14.4$ & $16.7 \pm 4.3$ & $18.8 \pm 7.3$ & $15.6 \pm 7.5$ \\
3.0 & $10.3 \pm 6.0$ & $13.0 \pm 4.1$ & $9.5 \pm 4.6$ & $9.8 \pm 2.2$ & $7.9 \pm 4.6$ & $8.6 \pm 4.3$ \\
4.0 & $7.1 \pm 2.0$ & $10.2 \pm 2.0$ & $6.5 \pm 1.3$ & $7.5 \pm 2.3$ & $6.0 \pm 3.6$ & $6.2 \pm 3.6$ \\
\hline
\end{tabular}

Values are means $\pm \mathrm{SD}\{$ second $(n=6)\}$. Cont, control; Lac, lactose; GL, galactooligosaccharide; Neu5Ac, $N$-acetylneuraminic acid, SL, sialyllactose; GN, galactosylated $N$-acetylneuraminic acid.

Table 4. The effects of experimental diets on body weight, food intake, food efficiency and brain weight in rats.

\begin{tabular}{lcccccc}
\hline & Cont & Lac & GL & Neu5Ac & SL & GN \\
\hline Initial weight $(\mathrm{g})$ & $322 \pm 7$ & $326 \pm 9$ & $325 \pm 10$ & $325 \pm 9$ & $326 \pm 6$ & $321 \pm 9$ \\
Final weight $(\mathrm{g})$ & $446 \pm 11$ & $438 \pm 25$ & $435 \pm 23$ & $440 \pm 25$ & $434 \pm 19$ & $427 \pm 20$ \\
Weight gain $(\mathrm{g})$ & $125 \pm 13$ & $111 \pm 23$ & $111 \pm 19$ & $114 \pm 22$ & $108 \pm 16$ & $107 \pm 16$ \\
Food intake $(\mathrm{g})$ & $466 \pm 32$ & $454 \pm 40$ & $446 \pm 36$ & $437 \pm 38$ & $439 \pm 41$ & $433 \pm 44$ \\
Food efficiency $(\%)$ & $27 \pm 2$ & $24 \pm 3$ & $25 \pm 3$ & $26 \pm 3$ & $25 \pm 2$ & $25 \pm 2$ \\
\hline Brain weight $(\mathrm{g})$ & $2.0 \pm 0.1$ & $1.9 \pm 0.1$ & $1.9 \pm 0.1$ & $1.9 \pm 0.1$ & $2.0 \pm 0.1$ & $1.9 \pm 0.1$ \\
\hline
\end{tabular}

Values are means \pm SD $(n=6)$. Cont, control; Lac, lactose; GL, galactooligosaccharide; Neu5Ac, $N$ acetylneuraminic acid, SL, sialyllactose; GN, galactosylated $N$-acetylneuraminic acid. 


\section{Serum sialic acid.}

The sialic acid contents in the serum in each group of rats after feeding of the control diet, lactose, GL, Neu5Ac, SL or GN are shown in Table 5. The sialic acid content was higher in the groups that had been fed GN, SL and Neu5Ac than in the other groups, but the differences were not statistically significant.

\section{Brain lipid composition.}

The results of the lipid composition of the brain after feeding of the control diet, lactose, GL, Neu5Ac, SL or GN are shown in Table 6. The triacylglycerol content was significantly lower in the GN group compared with the other groups, while the phospholipid concentration was significantly higher. However, no changes in the fatty acid composition of the brain were observed. The brain ganglioside content was significantly higher in the SL and GN groups, but not in the Neu5Ac group, in comparison with the other three groups.

\section{Brain gangliosides.}

The ganglioside composition of the brain after the feeding the six diets is shown in Table 7. The GM3 or GD1a

Table 5. The effects of experimental diets on serum $N$ acetylneuraminic acid (Neu5Ac) concentration in rats.

\begin{tabular}{ll}
\hline \multicolumn{1}{c}{ Groups } & Total Neu5Ac $(\mathrm{mg} / \mathrm{dL})$ \\
\hline Control & $118.4 \pm 10.4$ \\
Lactose & $114.4 \pm 8.0$ \\
Galactooligosaccharide & $116.7 \pm 11.1$ \\
$N$-acetylneuraminic acid & $121.4 \pm 9.7$ \\
Sialyllactose & $123.9 \pm 14.3$ \\
Galactosylated $N$-acetylneuraminic acid & $122.9 \pm 15.5$ \\
\hline
\end{tabular}

Values are means \pm SD $(n=6)$. content were significantly higher in the GN and SL groups than in control, lactose or GL groups, and the GM 3 content was also significantly higher in the Neu5Ac groups than in the lactose or GL group. On the other hand, the GD2 content was significantly higher in the GN groups than in control, lactose or GL groups. In addition, GD1b and GT3 tended to be higher in the SL and GN groups than in other groups.

In the T-maze test, it was observed during the first day of the trials that the groups that had been fed GN and SL swam faster to the goal than the other groups. In the Morris swimming-maze test, the GN and SL groups reached the goal faster than the other groups during both the first and the second days of the trials. This tendency was clearer in the Morris swimming maze test than in the multiple T-maze test. These results suggest that the feeding of GN or SL accelerated this learning behavior in the adult rats.

To study the relationship between the improvement in this learning behavior and brain lipids in the SL and GN groups, the brain lipid composition of the rats was analysed. In the GN group, the triacylglycerol content was significantly lower than in the other groups, while the phospholipid content was significantly higher than in the other groups. The fatty acid composition of the phospholipids in this group did not differ from that of the other groups. In the SL group, the phospholipid content was not significantly higher than in the other groups. Phospholipids are regarded as important brain components and are related to the plasticizing and fluid abilities of the brain, ${ }^{21-23)}$ but it has not yet been established whether the phospholipid content and composition of the brain is related to its memorizing ability. We could not clarify a positive relationship between the brain phospholipid con-

Table 6. The effects of experimental diets on lipid composition in rat brain (mg/g wet brain).

\begin{tabular}{lrrrrrr}
\hline \multicolumn{1}{c}{ Lipids } & \multicolumn{1}{c}{ Cont } & Lac & GL & Neu5Ac & SL & GN \\
\hline Triacylglyceride & $5.1 \pm 0.8$ & $4.9 \pm 0.3$ & $5.0 \pm 0.3$ & $5.4 \pm 0.5$ & $5.5 \pm 0.9$ & $3.9 \pm 0.3^{\text {a,c,d,e }}$ \\
Cholesterol & $9.5 \pm 0.7$ & $9.4 \pm 0.5$ & $9.4 \pm 0.5$ & $10.0 \pm 0.5$ & $10.2 \pm 0.7$ & $10.7 \pm 1.1$ \\
Phospholipid & $33.0 \pm 1.5$ & $34.1 \pm 1.3$ & $34.5 \pm 1.3$ & $35.2 \pm 1.6$ & $34.0 \pm 1.1$ & $36.7 \pm 1.6^{\text {a,b,c,e }}$ \\
Ganglioside (as Neu5Ac) & $0.9 \pm 0.1$ & $0.8 \pm 0.1$ & $0.8 \pm 0.1$ & $0.9 \pm 0.1$ & $1.1 \pm 0.1^{\text {a,b,c }}$ & $1.1 \pm 0.1^{\text {a,b,c }}$ \\
\hline
\end{tabular}

Values are means \pm SD $(n=6)$. Cont, control; Lac, lactose; GL, galactooligosaccharide; Neu5Ac, $N$ acetylneuraminic acid, SL, sialyllactose; GN, galactosylated $N$-acetylneuraminic acid. ${ }^{\text {a Significantly different }}$ from Cont group $(p<0.05)$. ${ }^{\mathrm{b}}$ Significantly different from Lac group $(p<0.05)$. 'Significantly different from GL group $(p<0.05)$. ${ }^{\mathrm{d}}$ Significantly different from Neu5Ac group $(p<0.05)$. ${ }^{\mathrm{e}}$ Significantly different from SL group $(p<$ $0.05)$.

Table 7. The effects of experimental diets on gangliosides composition in rat brain $(\mu \mathrm{g} / \mathrm{g}$ wet brain).

\begin{tabular}{ccccccc}
\hline Gangliosides & Cont & Lac & GL & Neu5Ac & SL & GN \\
\hline GM3 & $13.6 \pm 2.7$ & $9.3 \pm 2.7$ & $11.2 \pm 2.5$ & $20.1 \pm 4.5^{\mathrm{b}, \mathrm{c}}$ & $23.4 \pm 3.3^{\mathrm{a}, \mathrm{b}, \mathrm{c}}$ & $23.0 \pm 4.0^{\mathrm{a}, \mathrm{b}, \mathrm{c}}$ \\
GM1 & $147.1 \pm 22.8$ & $96.7 \pm 27.6$ & $108.5 \pm 25.1$ & $130.3 \pm 31.5$ & $122.3 \pm 31.0$ & $111.5 \pm 24.7$ \\
GD3 & $9.7 \pm 6.0$ & nd & nd & $2.22 \pm 2.3$ & nd & nd \\
GD1a & $287.0 \pm 32.8$ & $292.2 \pm 39.1$ & $279.7 \pm 38.7$ & $332.2 \pm 31.5$ & $397.7 \pm 31.0^{\mathrm{a}, \mathrm{b}, \mathrm{c}}$ & $404.6 \pm 24.7^{\mathrm{a}, \mathrm{b}, \mathrm{c}}$ \\
GD2 & $44.1 \pm 19.0$ & $44.5 \pm 5.7$ & $43.0 \pm 8.0$ & $56.4 \pm 16.0$ & $53.4 \pm 9.1$ & $76.6 \pm 7.1^{\text {a,b,c }}$ \\
GD1b & $138.1 \pm 24.4$ & $130.6 \pm 7.0$ & $133.5 \pm 17.5$ & $144.7 \pm 41.6$ & $170.6 \pm 8.7$ & $160.0 \pm 13.8$ \\
GT3 & $190.2 \pm 18.7$ & $183.2 \pm 7.7$ & $194.6 \pm 37.6$ & $191.7 \pm 64.4$ & $224.8 \pm 17.6$ & $213.7 \pm 21.5$ \\
GQ1b & $58.5 \pm 15.5$ & $63.5 \pm 11.4$ & $61.7 \pm 15.3$ & $52.4 \pm 17.1$ & $57.9 \pm 15.2$ & $64.2 \pm 15.5$ \\
\hline
\end{tabular}

Values are means \pm SD $(n=6)$. Cont, control; Lac, lactose; GL, galactooligosaccharide; Neu5Ac, $N$ -

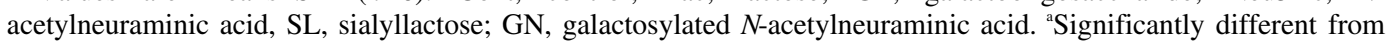
Cont group $(p<0.05)$. 'Significantly different from Lac group $(p<0.05)$. 'Significantly different from GL group $(p$ $<0.05)$. 
tent and the improvement of this learning behavior, because the brain phospholipid content was significantly higher in the group that had been fed GN than in the other groups, while in the group that had been fed SL it was not, despite the fact that the learning behaviors had a tendency to be improved in both the GN and the SL groups. Although the class of brain phospholipids in these rats was not studied, further studies may clarify the correlation of the class of these phospholipids and the improvement in the learning behavior in these rats.

The brain ganglioside content was significantly higher by 1.2 times in the groups fed GN or SL than in the other groups, but not in the Neu5Ac group. In addition, the GM3 content was higher by 1.5 to 2 times in GN, SL and Neu5 Ac groups than in the other groups. GD1a content was significantly higher in GN and SL than in the others, and the GD2 content was significantly higher in GN than in the control, lactose or GL groups. On the other hand, the GD1a content was significantly higher in the GN groups than in the others. GD1b and GT3, in addition, tended to be higher in the SL and GN groups than in other groups. These observations suggest that the improvement in the swimming learning behavior in the GN and SL groups might be due to an increase in the brain ganglioside contents in these groups. It was concluded that this tendency was more remarkable in the sialyl-oligosaccharides (GN and SL) feeding groups than in the free Neu5Ac feeding groups. However, the mechanism by which the increase of brain GM3, GD1a or GD2 causes the improvement of this learning behavior was unclear at this stage.

Carlson and House reported that the sialic acid content of the cerebrum and cerebellum increased by about 1.2 times after feeding Neu5Ac to in infant rats for 7 days at $20 \mathrm{mg} / \mathrm{kg} /$ day. ${ }^{24)}$ Morgan and Winick reported that the brain ganglioside content increased by 1.2 times in newborn rats after feeding Neu5Ac for 7 days at $20 \mathrm{mg} / \mathrm{kg}$ / day, and their learning behavior improved. ${ }^{25)}$ In our study, about $1000 \mathrm{mg} / \mathrm{kg} /$ day of GN or SL were fed to adult rats; this was equivalent to about $500 \mathrm{mg} / \mathrm{kg} /$ day in terms of Neu5Ac. This is 25 times larger than in the experiments by Carlson and House, and Morgan and Winick..$^{24,25)}$ The brain ganglioside content also increased by about 1.2 times in our feeding studies using GN or SL, and there tended to be an improvement in the learning behavior of these two groups. These observations suggest that the increase in brain gangliosides by about 1.2 times produced by feeding Neu5Ac-containing components contributed to the improvement in rat learning behavior.

However, the following sequences of sialic acid metabolism have not been clarified: the absorption of sialic acid in small intestine, metabolism of sialic acid in liver, transport of this metabolite across the blood-brain barrier and biosynthesis of brain ganglioside using the metabolite. Further study in feeding of radio-labeled sialic acid components will clarify these sequences from sialic acid feeding to brain ganglioside biosynthesis as well as the mechanism of the improvement of the learning behavior.

It is generally considered that gangliosides have effects on the nervous system in the brain. The ganglioside content in the brain is significantly higher than in other tissues and this content increases in the infant during the formation of the nervous system, ${ }^{26,27)}$ while it decreases during aging of the adult. ${ }^{28)}$ Since brain gangliosides are considered to have an effect on the discharge of neurotransmitters, the differentiation of neurons and synaptogenesis, some gangliosides have been used for neuron disability therapy. ${ }^{28,29)}$ It has been reported that administration of GM1 to rats that are models for Parkinson's disease accelerates the recovery of dopamine concentrations in the brain $^{30-32)}$ and that these rats improved in their behavior. ${ }^{33,34)}$ It has been also reported that the administration of GM1 to diabetic patients with peripheral nervous disease had a therapeutic effect. Thus, there is evidence supporting a relationship between administration of gangliosides and improvement in the brain neuron system.

In our study with adult rats, the groups that had been fed with sialyl-oligosaccharides, including GN and SL, had the tendency of improvement of learning behavior in the multiple T-maze test as well as in the Morris swimming-maze test. In these groups, the contents of brain ganglioside increased, and in addition, the compositions of brain gangliosides changed.

It is well known that the brain ganglioside content increases during infancy, then remains steady and finally decreases step by step during aging. Our results suggest that the intake of Neu5Ac-containing components may reduce the decline in brain activity that occurs during aging.

\section{REFERENCES}

1 ) R.W. Veh, J.C. Michalski, A.P. Corfield, M. Sander-Wewer, D. Gies and R. Schauer: New chromatographic system for the rapid analysis and preparation of colostrum sialyloligosaccharides. J. Chromatogr., 212, 313-322 (1981).

2 ) E. Nobile-Orazio, M. Carpo and G. Scarlato: Gangliosides. Their role in clinical neurology. Drugs, 47, 576-585 (1994).

3 ) B. Wang and J. Brand-Miller: The role and potential of sialic acid in human nutrition. Eur. J. Clin. Nutr., 57, 1351-1369 (2003).

4 ) R. Schauer: Origin and biological role of the great chemical diversity of natural sialic acids. Trend Glycosci. Glycotechnol., 9, 315-330 (1997).

5 ) S. Fukuta, J.L. Magnani, E.M. Twiddy, R.K. Holmes and V. Ginsburg: Comparison of the carbohydrate-binding specificities of cholera toxin and Escherichia coli heat-labile enterotoxins LTh-I, LT-IIa, and LT-IIb. Infect. Immun., 56, 1748-1753 (1988).

6 ) Y. Suzuki, Y. Nagao, H. Kato, M. Matsumoto, K. Nerome, K. Nakajima and E. Nobusawa: Human influenza A virus hemagglutinin distinguishes sialyloligosaccharides in membraneassociated gangliosides as its receptor which mediates the absorption and fusion processes of virus infection. Specificity for oligosaccharides and sialic acids and the sequence to which sialic acid is attached. J. Biol. Chem., 261, 17057-17061 (1986).

7 ) B. Wang, P. McVeagh, P. Petocz and J. Brand-Miller: Brain ganglioside and glycoprotein sialic acid in breastfed compared with formula-fed infants. Am. J. Clin. Nutr., 78, 1024-1029 (2003).

8 ) S.E. Carlson: $N$-acetylneuraminic acid concentrations in human milk oligosaccharides and glycoproteins during lactation. Am. J. Clin. Nutr., 41, 720-726 (1985).

9 ) T. Urashima, T. Saito, T. Nakamura and M. Messer: Oligosaccharides of milk and colostrum in non-human mammals. Glycoconj. J., 18, 357-371 (2001).

10) T. Nakamura, H. Kawase, K. Kimura, Y. Watanabe, M. Ohtani, I. Arai and T. Urashima: Concentrations of sialyloligosaccharides in bovine colostrum and milk during the prepartum 
and early lactation. J. Dairy Sci., 86, 1315-1320 (2003).

11) W. Sumiyoshi, T. Urashima, T. Nakamura, I. Arai, T. Nagasawa, T. Saito, N. Tsumura, B. Wang, J. Brand-Miller, Y. Watanabe and K. Kimura: Sialyl oligosaccharides in the milk of Japanese women: Changes in concentration during the course of lactation. J. Appl. Glycosci., 50, 461-467 (2003).

12) S. Yanahira, Y. Yabe, M. Nakakoshi, S. Miura, N. Matsubara and H. Ishikawa: Structures of novel acidic galactooligosaccharides synthesized by Bacillus circulans $\beta$-galactosidase. Biosci. Biotechnol. Biochem., 62, 1791-1794 (1998).

13) E. Deya, Y. Ikeuchi, H. Yoshida, Y. Hiraoka and Y. Uchida: High purity sialic acid and process for the preparation there of. Jpn. Patent Pat. No. 07-103139 (1995).

14) Y. Ikeuch and T. Yakabe: Sialic acid and process for the preparation from cheese whey. US Patent Pat. No. 5,679,645 (1997).

15) E. Deya, M. Amaya, K. Nojiri and S. Igarashi: Preparation of galactosyl-lactose by $\beta$-galactosidase. Rep. Res. Lab. Snow Brand Milk Prod. Co. Ltd., 78, 19-26 (1982).

16) O. Ishizaki: Learning behavior of rats on the water maze. Jikken Dobutsu, 27, 9-12 (1978).

17) R. Morris: Developments of a water-maze procedure for studying spatial learning in the rat. J. Neurosci. Methods, 11, 47-60 (1984).

18) L. Svennerholm and P. Fredman: A procedure for the quantitative isolation of brain gangliosides. Biochim. Biophys. Acta, 617, 97-109 (1980).

19) S. Ren, J.N. Scarsdale, T. Ariga, Y. Zhang, R.A. Klein, R. Hartmann, Y. Kushi, H. Egge and R.K. Yu: $O$-acetylated gangliosides in bovine buttermilk. Characterization of 7-O-acetyl, 9-O-acetyl, and 7,9-di-O-acetyl GD3. J. Biol. Chem., 267, 12632-12638 (1992).

20) S. Ando, H. Waki and K. Kon: High-performance liquid chromatography of underivatized gangliosides. J. Chromatogr., 408, 285-290 (1987).

21) Y. Tanaka and S. Ando: Synaptic aging as revealed by changes in membrane potential and decreased activity of $\mathrm{Na}^{+}$, $\mathrm{K}^{+}$-ATPase. Brain Res., 506, 46-52 (1990).

22) P. Mecocci, A. Cherubini, M. F. Beal, R. Cecchetti, F. Chionne, M.C. Polidori, G. Romano and U. Senin: Altered mitochondrial membrane fluidity in AD brain. Neurosci. Lett., 207, 129-132 (1996).

23) U. Igbavboa, N.A. Avdulov, F. Schroeder and W.G. Wood: Increasing age alters transbilayer fluidity and cholesterol asymmetry in synaptic plasma membranes of mice. J. Neurochem., 66, 1717-1725 (1996).

24) S.E. Carlson and S.G. House: Oral and intraperitoneal administration of $\mathrm{N}$-acetylneuraminic acid: effect on rat cerebral and cerebellar $N$-acetylneuraminic acid. J. Nutr., 116, 881-886 (1986).

25) B.L. Morgan and M. Winick: Effects of environmental stimulation on brain $\mathrm{N}$-acetylneuraminic acid content and behavior. J. Nutr., 110, 425-432 (1980).

26) R.K. Yu, L.J. Macala, T. Taki, H.M. Weinfield and F.S. Yu: Developmental changes in ganglioside composition and synthesis in embryonic rat brain. J. Neurochem., 50, 1825-1829 (1988).

27) M.T. Vanier, M. Holm, R. Ohman and L. Svennerholm: Developmental profiles of gangliosides in human and rat brain. $J$. Neurochem., 18, 581-592 (1971).

28) S. Ando, Y. Tanaka, Y. Toyoda and K. Kon: Membrane aging of the brain synaptosomes with special reference to ganglioside. in Ganglioside and neuronal plasticity. Fidia Research Series Vol. 6, Liviana Press Padova, Rome, pp. 105112 (1988).

29) A. Leon, L. Facci, G. Toffano, S. Sonnino and G. Tettamanti: Activation of $\mathrm{Na}^{+} / \mathrm{K}^{+}$-ATPase by nanomolar concentrations of GM1 ganglioside. J. Neurochem., 37, 350-357 (1981).

30) J.S. Schneider, A. Pope, K. Simpson, J. Taggart, M.G. Smith and L. DiStefano: Recovery from experimental parkinsonism in primates with GM1 ganglioside treatment. Science, 256, 843846 (1992).

31) M.T. Herrero, A. Kastner, I. Perez-Otano, E.C. Hirsch, M.R. Ruquin, F. Javoy-Agid, J. Del Rio, J.A. Obeso and Y. Agid: Gangliosides and parkinsonism. Neurology, 43, 2132-2134 (1993).

32) J.S. Schneider and L. DiStefano: Oral administration of semisynthetic sphingolipids promotes recovery of striatal dopamine concentrations in a murine model of parkinsonism. Neurology, 44, 748-750 (1994).

33) S.H. Horowitz: Ganglioside therapy in diabetic neuropathy. Muscle Nerve, 9, 531-536 (1986).

34) M. Hallett, T. Flood, N. Slater and J. Dambrosia: Trial of ganglioside therapy for diabetic neuropathy. Muscle Nerve, 10, 822-825 (1987).

\section{成熟ラットの水泳学習行動と脳内脂質組成に及ぼす} シアリルラクトースとガラクトシルシアル酸の影響

酒井史彦 ${ }^{1}$, 池内義弘 ${ }^{1}$, 浦島 匡 $^{2}$, 藤原三知雄 ${ }^{3}$ 大柣健蔵 ${ }^{3}$, 柳平修一 ${ }^{1}$

1 雪印乳業株式会社食品衛生研究所

(350-1165 川越市南台 1-1-2)

2 帯広畜産大学大学院畜産学研究科食肉乳衛生学講座 (080-8555 带広市稲田町西 2 線 11 番地)

3 北里大学医療衛生学部遺伝生化学

(228-8555 相模原市北里 1-15-1)

乳から調製したシアリルラクトース $(\mathrm{SL})$ と $\beta$-ガラクト シダーゼの糖転移反応で酵素合成したガラクトシルシア ル酸(GN)について, 成熟ラットの水泳学習行動と脳内脂 質組成との関係に着目して解析を行った. その結果, SL や GN 投与群の水泳学習行動は, 対照に用いたシアル酸 やガラクトオリゴ糖および乳糖投与群と比較して向上す る傾向にあった。また，SLや GNを投与したラットでは 脳内のリン脂質やガングリオシドが有意に増加すること が明らかとなった。リン脂質やガングリオシドは脳内脂 質を構成する重要な成分であり, 乳児期で急激に増加し た後，一定の水準となり，その後高齢化に伴い減少する ことが知られている。 